\title{
Pembinaan untuk Meningkatkan Kemampuan Guru SMK dalam Menyusun Administrasi Penelitian Tindakan Kelas
}

\section{Coaching to Enhance Capabilities of Vocational Teachers in Developing Class Action Research Administration}

\author{
Slamet Heryadi \\ SMK Negeri 15, Bandung, Jawa Barat, Indonesia \\ slamet_heryadi45@yahoo.com \\ Naskah diterima tanggal 18/3/2018, Direvisi akhir tanggal 15/7/2018, disetujui tanggal 15/8/2018
}

\begin{abstract}
Abstrak
Proses belajar mengajar yang dilaksanakan di sekolah merupakan salah satu wahana untuk mengembangkan seluruh potensi peserta didik. Hasil belajar siswa akan meningkat jika guru mengimplementasikan kemampuan pedagogik dan profesional dalam pembelajaran. Salah satu upaya untuk meningkatkan kemampuan pedagogik dan profesional guru yaitu memotivasi dan mendorong guru untuk melaksanakan penelitian tindakan kelas. Tujuan penelitian tindakan kelas yaitu: (1) meningkatkan mutu isi, masukan, proses, serta hasil pendidikan dan pembelajaran di sekolah; (2) membantu guru dan tenaga kependidikan lainnya mengatasi masalah pembelajaran dan pendidikan di dalam dan di luar kelas; (3) meningkatkan sikap professional pendidik dan tenaga kependidikan; (4) menumbuhkembangkan budaya akademik di lingkungan sekolah sehingga tercipta sikap proaktif di dalam melakukan perbaikan mutu pendidikan dan pembelajaran secara berkelanjutan. Selain itu dengan melaksanakan penelitian tindakan kelas akan terjadi perbaikan mutu, proses, dan hasil pembelajaran tujuan penelitian tindakan kelas adalah meningkatkan mutu proses dan hasil pembelajaran, mengatasi masalah pembelajaran, meningkatkan profesionalisme, dan menumbuhkan budaya akademik. Metode penelitian yang digunakan adalah penelitian tindakan sekolah yaitu melaksanakan pembinaan bagi sekelompok guru di suatu sekolah, melalui beberapa siklus, mengunakan sistem spiral refleksi model Kemmis dan Mc Taggart yang dimodifikasi. Strategi/Metode Kerja/Teknik Pembinaan yang digunakan pada siklus 1 adalah Observasi-Refleksi-Rekomendasi, Focused Group Discussion, sedangkan pada siklus 2 adalah metode Delphi, serta Observasi-Refleksi-Rekomendasi. Hasil penelitian menunjukkan bahwa setelah pembinaan, kinerja guru dalam membuat administrasi penelitian tindakan kelas mulai dari membuat RPP untuk setiap siklus, membuat LKS/soal tes untuk setiap siklus, membuat angket respon siswa, membuat pedoman observasi keaktifan siswa, membuat daftar check, membuat format observasi keaktifan siswa, membuat format observasi pelaksanaan model pembelajaran oleh guru dan siswa, dan membuat format diskusi balikan, sudah menunjukkan adanya peningkatan, dari siklus I ke siklus II. Siklus II mengakhiri pembinaan, dengan indikator keaktifan guru telah diatas $80.00 \%$ dan skor guru minimal 80.00 sudah diatas $85 \%$.
\end{abstract}

Kata kunci: kemampuan guru, dan penelitian tindakan kelas.

\begin{abstract}
The learning process that implemented in school is one tool to develop the full potential of learners. Student learning outcomes will increase if the teacher implements pedagogical and professional ability in learning. One effort to improve pedagogical and professional teachers that motivate and encourage teachers to carry out action research. The purpose of classroom action research are: (1) improve the quality of the content, input, process, and outcomes of education and learning; (2) help teachers and other education personnel to overcome the problem of learning and education within and outside the classroom; (3) enhance the professional attitude of educators and education personnel; (4) develop an academic culture in the school environment so as to create a proactive stance in the improvement of education quality and learning on an ongoing basis. In addition to carrying out action research will be improvement of quality,
\end{abstract}


process, and learning outcomes of classroom action research objectives is to improve the quality of learning process and results, overcome learning problems, improve professionalism, and foster a culture of academic. The method used is action research in school, carry out training for a group of teachers in a school, through several cycles, using a system of spiral reflection Kemmis models and Mc Taggart modified. Strategies/Working Methods/ Techniques Coaching used in first cycle is the Observation-Reflection-Recommendations, Focused Group Discussion, while the second cycle is the Delphi method, as well as the Observation-ReflectionRecommendation. The results showed that after training, the performance of teachers in making the administration of classroom action research ranging from making lesson plans for each cycle, making test items for each cycle, making the student questionnaire responses, making the observation guide students' activity, making a list of the check, making format observation student activity, making observations format implementation model of learning by teachers and students, and create a feedback discussion format, the results have shown an increase from the first cycle to the second cycle. Cycle 2 put an end to coaching with the activity indicator has been above $80.00 \%$ teachers and teacher score a minimum of 80.00 is already above $85 \%$.

Keywords: ability of teachers, and class action research.

\section{PENDAHULUAN}

Dalam Undang-undang RI Nomor 20 tahun 2003 tentang sistem pendidikan nasional Bab I Pasal I (1) menyatakan bahwa, pendidikan adalah "usaha sadar dan terencana untuk mewujudkan suasana belajar dan proses pembelajaran agar peserta didik secara aktif mengembangkan potensi dirinya untuk memiliki kekuatan spiritual keagamaan, pengendalian diri, kepribadian, kecerdasan, akhlak mulia serta keterampilan dirinya, masyarakat, bangsa dan negara”.

Proses belajar mengajar yang dilaksanakan di sekolah merupakan salah satu wahana untuk mengembangkan seluruh potensi peserta didik (Dahar, 1985; Rusman, 2010; Eggen \& Kauchak, 2012). Hasil belajar siswa akan meningkat jika guru mengimplementasikan kemampuan pedagogik dan profesional dalam pembelajaran (Retno, 2003; Rusman, 2010; Sumantri \& Permana, 2001; Udin, 1992). Salah satu upaya untuk meningkatkan kemampuan pedagogik dan profesional guru salah satunya secara periodik, guru melaksanakan penelitian tindakan kelas. Dengan melaksanakan penelitian tindakan kelas maka permasalahan nyata yang terjadi di dalam kelas, akan terpecahkan.

Menurut Sumarno(2005), tujuan penelitian tindakan kelas adalah meningkatkan mutu proses dan hasil pembelajaran, mengatasi masalah pembelajaran, meningkatkan profesionalisme, dan menumbuhkan budaya akademik. Sedangkan Arikunto (2006) merinci tujuan PTK, yaitu: (1) meningkatkan mutu isi, masukan, proses, serta hasil pendidikan dan pembelajaran di sekolah; (2) membantu guru dan tenaga kependidikan lainnya mengatasi masalah pembelajaran dan pendidikan di dalam dan di luar kelas; (3) meningkatkan sikap professional pendidik dan tenaga kependidikan; (4) menumbuhkembangkan budaya akademik di lingkungan sekolah sehingga tercipta sikap proaktif di dalam melakukan perbaikan mutu pendidikan dan pembelajaran secara berkelanjutan. Selain itu dengan melaksanakan penelitian tindakan kelas akan terjadi perbaikan mutu, proses, dan hasil pembelajaran, antara lain: (1) peningkatan atau perbaikan terhadap kinerja belajar siswa di sekolah; (2) peningkatan atau perbaikan terhadap mutu proses pembelajaran di kelas; (3) peningkatan atau perbaikan terhadap Jurnal Penelitian Pendidikan 
kualitas penggunaan media, alat bantu belajar, dan sumber belajar lainnya; alat bantu belajar, dan sumber belajar lainnya; (4) peningkatan atau perbaikan terhadap kualitas prosedur dan alat evaluasi yang digunakan untuk mengukur proses dan hasil belajar siswa; (5) peningkatan atau perbaikan terhadap masalah pendidikan anak di sekolah; (6) peningkatan atau perbaikan terhadap kualitas penerapan kurikulum dan pengembangan kompetensi siswa di sekolah. Namun pada kenyataannya di lapangan kemampuan guru dalam melaksanakan penelitian tindakan kelas masih perlu ditingkatkan.

Mutu pendidikan adalah fokus utama dalam pembangunan pendidikan dewasa ini, dan efektivitas pembelajaran oleh guru profesional adalah faktor utama peningkatan mutu pendidikan (Rusman, 2010; Harianto, 2000). Guru sebagai pendidik profesional dengan tugas utama mendidik, mengajar, membimbing, mengarahkan, melatih, menilai dan mengevaluasi peserta didik membutuhkan peningkatan profesional secara terus menerus (Udin, 1992; Winkell, 1993; Arikunto, 2003; Joyce et.al, 2009). Melalui penelitian tindakan kelas, seorang guru memperoleh pemahaman tentang apa yang harus dilakukan, merefleksi diri untuk memahami dan menghayati nilai pendidikan dan pembelajarannya sendiri, dapat bekerja secara kontekstual, dan mengerti sejarah tentang pendidikan dan persekolahannya (Sumarno, 2005). Sehubungan dengan itu, maka Penelitian Tindakan Kelas (PTK) memiliki potensi yang sangat besar untuk meningkatkan pembelajaran apabila diimplementasikan dengan baik dan benar. Sesungguhnya kegiatan penelitian telah banyak dilakukan. Namun sayangnya kegiatan penelitian tersebut kurang dirasakan dampaknya bagi peningkatan mutu pembelajaran. Menurut Wiriaatmadja (1999) hal tersebut setidaknya disebabkan oleh dua hal, yaitu: (1) pelaksanaan penelitian bidang pendidikan umumnya kurang melibatkan guru; (2) penyebarluasan (dissemination) hasil penelitian melalui publikasi ilmiah pada kalangan guru di lapangan memakan waktu sangat panjang. Selain itu, disebabkan karena kurangnya kesempatan guru mengakses hasil penelitian untuk perbaikan mutu pembelajaran.

Menurut Arikunto (2006) mengartikan penelitian tindakan kelas sebagai suatu pencermatan terhadap kegiatan belajar berupa sebuah tindakan, yang sengaja dimunculkan dan terjadi dalam sebuah kelas secara bersama. Karena itu penelitian tindakan yang dilakukan oleh guru ditujukan untuk meningkatkan situasi pembelajaran yang menjadi tanggung jawabnya. Hal tersebut sejalan dengan pendapat Sumarno (2005), menjelaskan bahwa penelitian tindakan merupakan intervensi praktik dunia nyata yang ditujukan untuk meningkatkan situasi praktis. Karena itu penelitian tindakan yang dilakukan oleh guru ditujukan untuk meningkatkan situasi pembelajaran yang menjadi tanggung jawabnya.

Hopkins (Sukidin, 2002), mengemukakan ada enam prinsip yang harus diperhatikan dalam PTK, yaitu: (1) Metoede PTK yang diterapkan seyogyanya tidak mengganggu komitmen sebagai pengajar; (2) metode pengumpulan data yang digunakan tidak menuntut waktu yang berlebihan karena dilakukan sesuai dengan jadwal pelajaran; (3) 
metodologi yang digunakan harus reliable; (4) masalah program yang diusahakan adalah masalah yang merisaukan, dan didasarkan pada tanggung jawab professional; (5) Dalam menyelenggarakan PTK, guru harus selalu bersikap konsisten dan memiliki kepedulian tinggi terhadap proses dan prosedur yang berkaitan dengan pekerjaannya; (6) PTK tidak dilakukan sebatas dalam konteks kelas atau mata pelajaran tertentu melainkan dengan perspektif misi sekolah secara keseluruhan. Sedangkan menurut Arikunto (2006) prinsip-prinsip PTK yang harus dipetrhatikan apabila ingin melakukan PTK dengan baik, yaitu: (1) Kegiatan nyata dalam situasi rutin, yaitu penelitian dilakukan tanpa mengubah situasi rutin; (2) adanya kesadaran diri untuk memperbiki kinerja; (3) SWOT sebagai dasar berpijak, yaitu penelitian tindakan harus dimulai dengan melakukan analisis SWOT; (4) PTK adalah upaya empiris dan sistremik; (5) mengikuti prinsip SMART dalam perencanaan, yaitu:

1. S-specifik, khusus, tidak terlalu umum

2. M-Managable, dapat dikelola, dilaksanakan

3. A-Acceptable, dapat diterima lingkungan, atau Achievable, dapat dicapai, dijangkau

4. R-Realistic, operasional, tidak di luar jangkauan, dan

5. T-Time-bound, diikat oleh waktu tertentu.

Tujuan penelitian tindakan kelas adalah untuk memperbaiki dan meningkatkan praktik pembelajaran di kelas secara berkesinambungan. Tujuanini "melekat" pada diri guru dalam penunaian misi professional kependidikannya (Sukidin, 2002). Hal ini menunjukkan bahwa sesungguhnya PTK bertujuan untuk memecahkan permasalahan nyata yang terjadi di dalam kelas. Karena itu menurut Sumarno (2005), tujuan penelitian tindakan kelas adalah meningkatkan mutu proses dan hasil pembelajaran, mengatasi masalah pembelajaran, meningkatkan profesionalisme, dan menumbuhkan budaya akademik. Sedangkan Arikunto (2006) merinci tujuan PTK, yaitu: (1) meningkatkan mutu isi, masukan, proses, serta hasil pendidikan dan pembelajaran di sekolah; (2) membantu guru dan tenaga kependidikan lainna mengatasi masalah pembelajaran dan pendidikan di dalam dan di luar kelas; (3) meningkatkan sikap professional pendidik dan tenaga kependidikan; (4) menumbuhkembangkan budaya akademik di lingkungan sekolah sehingga tercipta sikap proaktif di dalam melakukan perbaikan mutu pendidikan dan pembelajaran secara berkelanjutan.

Arikunto (2006) menjelaskan luaran yang dapat diperoleh melalui PTK, yaitu perbaikan mutu, proses, dan hasil pembelajaran, antara lain: (1) peningkatan atau perbaikan terhadap kinerja belajar siswa di sekolah; (2) peningkatan atau perbaikan terhadap mutu proses pembelajaran di kelas; (3) peningkatan atau perbaikan terhadap kualitas penggunaan media, alat bantu belajar, dan sumber belajar lainnya; alat bantu belajar, dan sumber belajar lainnya; (4) peningkatan atau perbaikan terhadap kualitas prosedur dan alat evaluasi yang digunakan untuk mengukur proses dan hasil belajar siswa; (5) peningkatan atau perbaikan terhadap masalah pendidikan anak di sekolah; (6) peningkatan atau perbaikan terhadap kualitas penerapan kurikulum dan 
pengembangan kompetensi siswa di sekolah.

Sebagaimana halnya dengan jenis penelitian yang lain, maka PTK harus memenuhi kriteria tertentu, yaitu harus memenuhi kriteria validitas. Akan tetapi, makna dasar validitas untuk penelitian tindakan condong ke makna dasar validitas dalam penelitian kualitatif, yaitu makna langsung dan lokal dari tindakan sebatas sudut pandang peserta penelitiannya. Jadi kredibilitas penafsiran peneliti dipandang lebih penting daripada validitas internal (Sumarno, 2005). Karena PTK bersifat transformatif, maka kriteria yang cocok adalah validitas demokratik, validitas hasil, validitas proses, validitas katalitik, dan validitas dialogis, yang harus dipenuhi dari awal sampai akhir penelitian, yaitu dari refleksi awal saat kesadaran akan kekurangan muncul sampai pelaporan hasil penelitiannya (Sukidin, 2002).

Untuk menjamin validitas PTK, dapat dilakukan dengan meminimalkan subjektivitas. Subjektivitas dapat dihindari melalui trianggulasi. Guru sebagai pelaku PTK dapat menggunakan metode ganda dan perspektif kolaborator untuk memperoleh gambaran yang kaya dan lebih objektif.

Bentuk lain dari trianggulasi adalah: trianggulasi waktu, trianggulasi ruang, trianggulasi peneliti, dan trianggulasi teoretis (Wiriaatmadja, 1999). Trianggulasi waktu dapat dilakukan dengan mengumpulkan data dalam waktu yang berbeda, sedapat mungkin meliputi rentangan waktu tindakan dilaksanakan dengan frekuensi yang memadai untuk menjamin bahwa efek perilaku tertentu bukan hanya suatu kebetulan.

Salah satu ciri khas PTK adalah kerja sama antara praktisi dengan peneliti dalam pemahaman, kesepakatan tentang permasalahan, pengambilan keputusan yang akhirnya melahirkan kesamaan tindakan. Kerja sama antara guru dengan peneliti merupakan hal yang sangat penting dalam menggali dan mengkaji permasalahan nyata yang dihadapi guru dan/atau siswa di sekolah. Kerja sama ini terutama pada kegiatan mendignosis masalah, menyusun usulan, melaksanakan tindakan, menganlisis data, menyeminarkan hasil, dan menyusun laporan akhir (Arikunto, 2006). Sehubungan dengan itu, maka ada beberapa butir penting tentang PTK kolaboratif sebagaimana yang dikemukakan oleh Sumarno (2005) yaitu: (1) penelitian tindakan yang sejati adalah penelitian tindakan kolaboratif, yaitu yang dilakukan oleh sekelompok peneliti melalui kerja sama dan kerja bersama, (2) penelitian kelompoktersebutdapat dilaksanakan melalui tindakan anggota kelompok perorangan yang diperiksa secara kritis melalui refleksi demokratik dan dialogis; (3) optimalisasi fungsi PTK kolaboratif dengan mencakup gagasan-gagasan dan harapanharapan semua orang yang terlibat dalam situasi terkait; (4) pengaruh langsung hasil PTK kepada guru dan murid-murid serta pada situasi dan kondisi yang ada.

Model PTK yang sering digunakan di dalam dunia pendidikan, di antaranya: (a) Model Kurt Lewin, (b) Model Kemmis dan Mc Taggart, (c) Model John Elliot, dan (4) Model Dave Ebbut. Yang akan digunakan dalam penelitian ini penelitian tindakan kelas model Kemis dan Mc Taggart.

Saat ini guru belum memiliki motivasi yang kuat untuk mengatasi masalah 
pembelajaran di dalam kelas, serta menuntaskan dan menentukan solusinya melalui penelitian tindakan kelas. Kondisi tersebut disebabkan juga karena guru banyak yang tidak tahu apa yang harus dipersiapkan apabila akan melaksanakan penelitian tindakan kelas. Salah satu persiapan dalam melaksanakan penelitian tindakan kelas yang belum diketahui guru adalah membuat dan mengembangkan administrasi penelitian tindakan kelas. Berdasarkan data di atas, mendorong peneliti telah melaksanakan penelitian untuk meningkatkan kemampuan guru SMK Negeri 15 Bandung dalam melaksanakan penelitian tindakan kelas, khusunya membuat administrasi penelitian tindakan kelas

\section{METODOLOGI PENELITIAN}

Penelitian ini menggunakan Penelitian Tindakan Sekolah yaitu melaksanakan pembinaan bagi sekelompok guru di suatu sekolah, melalui beberapa siklus, mengunakan sistem spiral refleksi model Kemmis dan Mc Taggart yang dimodifikasi (Sukidin dkk, 2002), dengan tahapan mulai dari merencanakan pembinaan setiap siklus, pelaksanan pembinaan setiap siklus, observasi pelaksanaan dan refleksi pembinaan setiap siklus, yang dilakukan dari siklus I sampai siklus II dan seterusnya sampai diperoleh rekomendasi kompetensi guru pada siklus terakhir tuntas. Indikator ketuntasan apabila telah mencapai $85 \%$ subjek daya serapnya $\geq$ 80\% (Sudjana, 2001; Arikunto, 2003).

Strategi/Metode Kerja/Teknik Pembinaan yang digunakan pada siklus 1 adalah Observasi-Refleksi-Rekomendasi, Focused Group Discussion, sedangkan pada siklus 2 adalah metode Delphi, serta ObservasiRefleksi-Rekomendasi. Subyek penelitian dalam penelitian ini adalah guru di SMK Negeri 15 Bandung, Jumlah guru yang diteliti sebanyak 41 orang.

Secara garus besar, prosedur siklus pada gambar 1 dilakukan melalui kegiatan perencanaan (plan), siklus (act), observasi (observe) dan refleksi (reflect). Adapun prosedur pengembangan model siklus yang dilaksanakan dalam penelitian ini dapat dilihat pada gambar 1 .

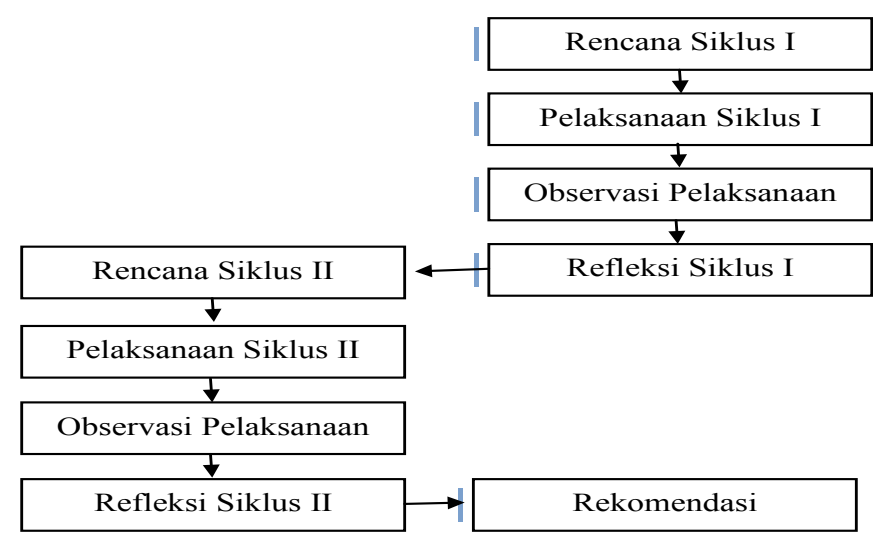

Bagan 1. Prosedur Pengembangan Model Siklus (Sukidin dkk, 2002).

Untuk memperoleh data yang diharapkan, maka dalam penelitian ini digunakan instrumen sebagai berikut: rencana pelaksanaan pembinaan, Pedoman observasi aktivitas guru, daftar chek aktivitas guru, instrumen evaluasi guru dalam membuat administrasi penelitian tindakan kelas, format observasi pembinaan, dan format diskusi balikan.

Data yang telah diperoleh pada setiap 
tahapan siklus diolah dan dinalisis melalui tahap-tahap sebagai berikut: kategori data, interpretasi data, validitas data, pelaksanaan siklus, evaluasi, analisis dan refleksi.

\section{HASIL DAN PEMBAHASAN}

\subsection{Hasil Penelitian}

1. Persiapan dan Pelaksaan Pembinaan Siklus I - II

Hasil observasi terhadap pelaksanaan pembinaan menunjukkan bahwa kemampuan guru dalam membuat administrasi penelitian tindakan kelas pada siklus II lebih baik dibanding siklus I, dengan demikian kegiatan pembinaan pada siklus II berupa kegiatan IHT telah meningkatkan kemampuan guru dalam membuat administrasi penelitian tindakan kelas. Peneliti dalam melakukan diskusi balikan, selalu memperhatikan kekurangan-kekurangan yang ada sehingga disempurnakan pada siklus selanjutnya. Catatan lapangan (lembar observasi) dan lembar diskusi balikan telah mencatat perubahan yang terjadi. Perubahan yang terjadi tidak hanya dari cara hasil pembinaan, tetapi dilihat juga dilihat dari proses pembinaannya, yaitu aktivitas guru. Aktivitas guru dan perolehan skor guru, selama pembinaan dari siklus I sampai siklus II telah mengalami perbaikan dan peningkatan.

2. Perubahan Aktivitas Guru dari Siklus 1 - Siklus II

PembinaanpadasiklusIItelahmemperlihatkan adanya peningkatan aktivitas guru dibanding pada siklus I, mulai dari membuat RPP untuk setiap siklus, membuat LKS/soal tes untuk setiap siklus, membuat angket respon siswa, membuat pedoman observasi keaktifan siswa, membuat daftar check, membuat format observasi keaktifan siswa, membuat format observasi pelaksanaan model pembelajaran oleh guru dan siswa, dan membuat format diskusi balikan. Aktifitas guru selama pembinaan pada siklus II dapat dilihat dari tabel 1 .

Tabel 1. Aktivitas Guru Selama Pembinaan dari Siklus I - siklus II

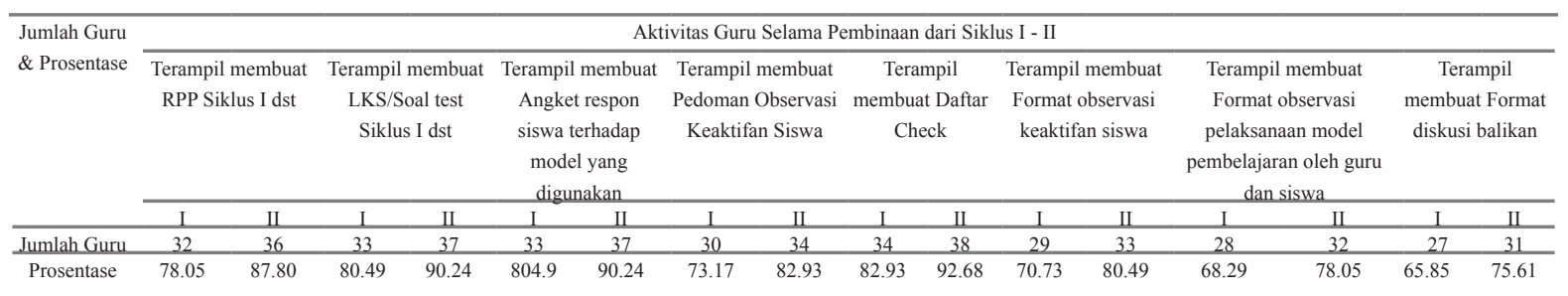

Data pada Tabel 1 di atas menunjukkan bahwa kemampuan guru dalam membuat RPP dengan terampil dari siklus I sampai siklus II mengalami peningkatan. Pada siklus I guru yang benar-benar terampil berjumlah 32 orang $(78.05 \%)$, dan pada siklus II berjumlah 36 orang $(87.80 \%)$. Dari siklus I ke siklus II mengalami peningkatan sebanyak 4 orang $(9.76 \%)$.

Kemampuan guru dalam membuat LKS/ Soal dengan terampil dari siklus I sampai siklus II mengalami peningkatan. Pada siklus I guru yang benar-benar terampil berjumlah 33 orang $(80.49 \%)$, dan pada siklus II berjumlah 37 orang (90.24\%). Dari siklus I ke siklus II mengalami peningkatan sebanyak 4 orang $(9.76 \%)$.

Data pada Tabel 1 di atas menunjukkan bahwa kemampuan guru dalam angket respon siswa terhadap model yang digunakan dengan terampil dari siklus I sampai siklus II mengalami peningkatan. Pada siklus I guru 
yang benar-benar terampil berjumlah 33 orang $(80.49 \%)$, dan pada siklus II berjumlah 37 orang (90.24\%). Dari siklus I ke siklus II mengalami peningkatan sebanyak 4 orang (9.76\%).

Kemampuan guru dalam membuat pedoman observasi keaktifan siswa dengan terampil dari siklus I sampai siklus II mengalami peningkatan. Pada siklus I guru yang benar-benar terampil berjumlah 30 orang $(73.17 \%)$, dan pada siklus II berjumlah 34 orang (82.93\%). Dari siklus I ke siklus II mengalami peningkatan sebanyak 4 orang $(9.76 \%)$.

Data pada Tabel 1 di atas menunjukkan bahwa kemampuan guru dalam membuat daftar check dengan terampil dari siklus I sampai siklus II mengalami peningkatan. Pada siklus I guru yang benar-benar terampil berjumlah 34 orang $(82.93 \%)$, dan pada siklus II berjumlah 38 orang (92.68\%). Dari siklus I ke siklus II mengalami peningkatan sebanyak 4 orang $(9.76 \%)$.

Data pada Tabel 1 di atas menunjukkan bahwa kemampuan guru membuat format observasi keaktifan siswa dengan terampil dari siklus I sampai siklus II mengalami peningkatan. Pada siklus I guru yang benar- benar terampil berjumlah 29 orang $(70.73 \%)$, dan pada siklus II berjumlah 33 orang (80.49\%). Dari siklus I ke siklus II mengalami peningkatan sebanyak 4 orang $(9.76 \%)$.

Kemampuan guru dalam membuat format observasi pelaksanaan model pembelajaran oleh guru dan siswa dengan terampil dari siklus I sampai siklus II mengalami peningkatan. Pada siklus I guru yang benarbenar terampil berjumlah 28 orang (68.29\%), dan pada siklus II berjumlah 32 orang (78.05\%). Dari siklus I ke siklus II mengalami peningkatan sebanyak 4 orang $(9.76 \%)$.

Data pada Tabel 1 di atas menunjukkan bahwa kemampuan guru dalam membuat format diskusi balikan dengan terampil dari siklus I sampai siklus II mengalami peningkatan. Pada siklus I guru yang benarbenar terampil berjumlah 27 orang $(65.85 \%)$, dan pada siklus II berjumlah 31 orang (75.61\%). Dari siklus I ke siklus II mengalami peningkatan sebanyak 4 orang $(9.76 \%)$.

\section{Skor Guru dari Siklus I - II}

Berdasarkan nilai skor guru SMK Negeri 15 Bandung pada siklus II menunjukkan adanya peningkatan dibanding siklus I. Peningkatan nilai skor guru dapat dilihat pada Tabel 2 .

Tabel 2. Skor Guru dari Siklus I - II

\begin{tabular}{cccc}
\hline \multirow{2}{*}{ No } & \multirow{2}{*}{ Kode Guru } & \multicolumn{2}{c}{ Nilai } \\
\cline { 3 - 4 } & & Siklus I & Siklus II \\
\hline 1 & AA & 83.33 & 91.67 \\
\hline 2 & AB & 83.33 & 91.67 \\
\hline 3 & AC & 75 & 83.33 \\
\hline 4 & AD & 75 & 93.33 \\
\hline 5 & AE & 83.33 & 83.33 \\
\hline 6 & AF & 75 & 91.67 \\
\hline 7 & AG & 83.33 & 91.67 \\
\hline 8 & AH & 83.33 & 91.67 \\
\hline 9 & AI & 83.33 & 83.33 \\
\hline 10 & AJ & 75 & 91.67 \\
\hline 11 & AK & 83.33 & 83.33 \\
\hline 12 & AL & 75 &
\end{tabular}




\begin{tabular}{|c|c|c|c|}
\hline 13 & $\mathrm{AM}$ & 75 & 83.33 \\
\hline 14 & AN & 83.33 & 91.67 \\
\hline 15 & $\mathrm{AO}$ & 83.33 & 91.67 \\
\hline 16 & $\mathrm{AP}$ & 83.33 & 91.67 \\
\hline 17 & AQ & 75 & 83.33 \\
\hline 18 & $\mathrm{AR}$ & 83.33 & 91.67 \\
\hline 19 & AS & 75 & 83.33 \\
\hline 20 & AT & 83.33 & 91.67 \\
\hline 21 & $\mathrm{AU}$ & 83.33 & 91.67 \\
\hline 22 & AV & 75 & 83.33 \\
\hline 23 & AW & 75 & 83.33 \\
\hline 24 & $\mathrm{AX}$ & 75 & 83.33 \\
\hline 25 & AY & 75 & 83.33 \\
\hline 26 & $\mathrm{AZ}$ & 83.33 & 91.67 \\
\hline 27 & $\mathrm{BC}$ & 83.33 & 91.67 \\
\hline 28 & $\mathrm{BD}$ & 83.33 & 91.67 \\
\hline 29 & $\mathrm{BE}$ & 75 & 83.33 \\
\hline 30 & $\mathrm{BF}$ & 75 & 83.33 \\
\hline 31 & BG & 75 & 83.33 \\
\hline 32 & $\mathrm{BH}$ & 83.33 & 91.67 \\
\hline 33 & BI & 83.33 & 91.67 \\
\hline 34 & BJ & 83.33 & 91.67 \\
\hline 35 & BK & 75 & 83.33 \\
\hline 36 & $\mathrm{BL}$ & 83.33 & 91.67 \\
\hline 37 & BM & 83.33 & 91.67 \\
\hline 38 & $\mathrm{BN}$ & 83.33 & 91.67 \\
\hline 39 & $\mathrm{BO}$ & 83.33 & 91.67 \\
\hline 40 & BP & 83.33 & 91.67 \\
\hline \multirow[t]{3}{*}{41} & BQ & 83.33 & 91.67 \\
\hline & Rata-rata & 79.91 & 88.38 \\
\hline & DSK & $63.41 \%$ & $100 \%$ \\
\hline
\end{tabular}

Berdasarkan data pada Tabel 2 di atas, diperoleh data sebagai berikut:

1. Pada Siklus I, skor tertinggi adalah 83.33, terendah 75.00 dan rata-ratanya adalah 79.91 serta jumlah guru yang mengalami ketuntasan belajarnya sebanyak 26 orang (63.41\%). tertinggi adalah 91.67, terendah 83.33 dan rata-ratanya adalah 88.38 serta jumlah guru yang mengalami ketuntasan belajarnya sebanyak 41 orang (100.00\%).

Adapun skor rata-rata pengerjaan LKS guru dapat dilihat pada Tabel 3.

2. Pada Siklus II, nilai rata-rata harian

Tabel 3. Skor Rata-rata Guru dari Siklus I - III

\begin{tabular}{ccc}
\hline \multicolumn{3}{c}{ Skor Rata-rata Guru } \\
\hline Siklus I & Siklus II \\
\hline 79.91 & 88.38 \\
\hline
\end{tabular}

Berdasarkan data pada Tabel 3 di atas, skor yang diperoleh guru dari siklus I sampai pada siklus II mengalami peningkatan. Pada siklus I skor rata-rata guru yaitu 79.91 point, dan pada siklus II yaitu 88.38 point, peningkatan yang terjadi sebesar 8.47 point. Begitu juga dengan Daya Serap Klasikal (DSK) mengalami peningkatan. Peningkatan DSK guru, dapat dilihat pada Tabel 4. 
Tabel 4. Daya Serap Klasikal (DSK) Guru Siklus I - III

\begin{tabular}{cc}
\hline \multicolumn{3}{c}{ Daya Serap Klasikal guru } \\
\hline Siklus I & Siklus II \\
\hline $63.41 \%$ & $100.00 \%$ \\
\hline
\end{tabular}

\subsection{Pembahasan}

1. Pengaruh Pembinaan Terhadap

Peningkatan Aktivitas Guru dari

Siklus I - Siklus II

Proses pembinaan dari siklus I sampai siklus II, aktivitas guru menunjukan pola yang aktif, serta antusias mengikuti setiap sesi pembinaan. Hampir semua guru berperan aktif membuat administrasi penelitian tindakan kelas, mulai dari mulai dari membuat RPP untuk setiap siklus, membuat LKS/soal tes untuk setiap siklus, membuat angket respon siswa, membuat pedoman observasi keaktifan siswa, membuat daftar check, membuat format observasi keaktifan siswa, membuat format observasi pelaksanaan model pembelajaran oleh guru dan siswa, dan membuat format diskusi balikan. Walaupun pada awalnya banyak yang belum terampil tetapi pada siklus II sudah menunjukkan kemajuan yang sangat pesat

2. Pengaruh Diterapkannya Pembinaan terhadap Kemampuan dan

Keterampilan Guru dalam membuat administrasi pembelajaran berbasis media pembelajaran.

Proses pembinaan dari siklus I sampai siklus II, skor guru menunjukan adanya peningkatan. Peningkatan itu menunjukkan bahwa setiap guru telah melaksanakan dan mengikuti tahap-tahap jalannya kegiatan pembinaan, serta menunjukan bahwa hampir semua guru berperan aktif mengikuti setiap sesi pembinaan yang dilakukan oleh peneliti. Sehingga pada saat dilaksanakan pengukuran kemampuan dan keterampilan guru dalam membuat administrasi penelitian tindakan kelas, pada siklus II, sudah $90.00 \%$ guru memperoleh skor 80.00 ke atas. Selain itu proses bimbingan dan arahan selama proses pembinaan yang dilakukan sudah diupayakan efektif, efisien dan intensif. Sehingga guru tidak mengalami kesulitan dalam melaksanakan proses pembinaan

\section{KESIMPULAN}

Proses pembinaan siklus I, menunjukkan bahwa aktivitas guru mulai dari membuat RPP untuk setiap siklus, membuat LKS/ soal tes untuk setiap siklus, membuat angket respon siswa, membuat pedoman observasi keaktifan siswa, membuat daftar check, membuat format observasi keaktifan siswa, membuat format observasi pelaksanaan model pembelajaran oleh guru dan siswa, dan membuat format diskusi balikan, belum memuaskan yaitu ada beberapa guru yang skornya masih belum optimum. Oleh karena itu kemampuan dan keahlian, serta Aktivitas guru dalam membuat administrasi penelitian tindakan kelas pada siklus I, perlu ditingkatkan dan harus diperbaiki pada siklus II. Pada siklus II, Aktivitas guru mulai dari mulai dari membuat RPP untuk setiap siklus, membuat LKS/soal tes untuk setiap siklus, membuat angket respon siswa, membuat pedoman observasi keaktifan siswa, membuat daftar check, membuat format observasi keaktifan siswa, membuat format observasi pelaksanaan model pembelajaran oleh guru dan siswa, dan membuat format diskusi balikan, sudah menunjukkan adanya Jurnal Penelitian Pendidikan 
peningkatan.

Selama proses pembinaan mulai dari siklus I sampai siklus II, peneliti berusaha melaksanakan bimbingan serta arahan secara adil, dan menyeluruh pada setiap guru, supaya setiap guru berpartisifasi dalam mengikuti setiap sesi pembinaan, mulai dari membuat RPP untuk setiap siklus, membuat LKS/ soal tes untuk setiap siklus, membuat angket respon siswa, membuat pedoman observasi keaktifan siswa, membuat daftar check, membuat format observasi keaktifan siswa, membuat format observasi pelaksanaan model pembelajaran oleh guru dan siswa, dan membuat format diskusi balikan.

\section{DAFTAR PUSTAKA}

Arikunto, S. (2003). Dasar-Dasar Evaluasi Pendidikan. Jakarta: Bumi Aksara.

Arikunto, S. (2006). Penelitian Tindakan. Jakarta: Bumi Aksara.

Dahar, R.W. (1985). Teori-Teori Belajar. Jakarta: Erlangga.

Eggen, P \& Kauchak, D. (2012). Strategi dan Model Pembelajaran: Mengajar Konten dan Keterampilan Berpikir, Edisi 6. Jakarta: PT. Indeks.

Harianto. (2000). Media Guru dan Model-model Pembelajaran. Jakarta: P2TK Depdikbud.

Joyce, B., Weil, M., \& E. Calhoun. (2009). Models of Teaching, Eighth ed. Boston: Allyn and Bacon.

Retno. (2003). Media Pendidikan dan Model Pembelajaran, Pengertian, Pengembangan, dan Pemanfaatannya. Jakarta: Rajawali.

Rusman. (2010). Model-Model Pembelajaran: Mengembangkan Profesionalisme Guru, Edisi 2. Jakarta: PT. Raja Grafindo Persada.

Sudjana. (2001). Penelitian dan Penilaian Pendidikan. Jakarta: Sinar Baru.

Sukidin. (2002). Manajemen Penelitian Tindakan Kelas. Jakarta: Insan Cendikia.

Sumantri \& Permana. (2001). Strategi Pembelajaran. Jakarta: Sinar Baru.

Sumarno, U. (2005). Penelitian Tindakan. Makalah. Universitas Pendidikan Indonesia. Tidak diterbitkan.

Udin, S. W. (1992). Strategi Pembelajaran. Jakarta: Depdikbud.

Winkell, W. S. (1993). Psikologi Guru. Jakarta: Gramedia.

Wiriaatmadja. (1999). Penelitian Tindakan dalam Bentuk Penelitian Siklus Sebagai Upaya Meningkatkan Kemahiran Profesional Dosen di Perguruan Tinggi. Jurnal Mimbar Penelitian. 